\title{
УДК 811.161.2’42
}

\section{Н. В. Кондратенко}

докторка філологічних наук, професорка, завідувачка кафедри прикладної лінгвістики

Одеського національного університету імені I. I. Мечникова

\section{СТЕРЕОТИПНЕ СПРИЙНЯТТЯ ЛЕКСЕМ ТЕМАТИЧНОЇ ГРУПИ «ІТАЛІЙСЬКА ЇЖА» НОСІЯМИ УКРАЇНСЬКОЇ МОВИ}

\begin{abstract}
У статті розглянуто номінаиії страв і напоїв італіської кухні, щчо є популярними в Україні і має відповідні назви в украӥнській мові. Дослідження представляє результати лінгвістичного експерименту, стимулом у якому слугувало словосполучення - номінація лексико-семантичної групи «італійська їжа». Виокремлено комплекс отриманих лексем, визначено характер семантичних зв'язків та основні семантичні групи номінацій, а також простежено особливості сприйняття інформантами поняття «італійська їжа», до якого було зараховано як номінації страв, так і напоїв. Визначено тематичні групи лексики на позначення італійських страв і напоїв, одержаних внаслідок проведеного лінгвістичного експерименту. Обгрунтовано стереотипний характер сприйняття італійської їжі та напоїв носіями украӥнської мови.
\end{abstract}

Ключові слова: лінгвосвідомість, лінгвістичний експеримент, лексико-семантична група, номінація страв, вербальна реакиія.

Постановка проблеми в загальному вигляді. Одним із завданням сучасних лінгвокультурології та міжкультурної комунікації є дослідження стереотипів сприйняття інших культур, віддзеркалених на вербальному рівні. Передусім це виражається в лексичних одиницях на позначення представників інших національностей, іншокультурних реалій, історичних фактів тощо. Серед таких лексем особливе місце належить одиницям лексико-семантичного поля «їжа та напої», що має національно-культурну специфіку в кожній мові, належить до загального культурного поняття національної кухні та відображає на вербальному рівні основні уподобання, традиції, звички представників різних національностей, представлені в галузі гастрономії. Національна їжа характеризує культуру народу не менше, ніж інші складники, а номінації їжі та напоїв вказують на уподобання, традиції, звички інших народів. Гастрономічні пріоритети навіть стають підгрунтям для утворення стилістично забарвлених номінацій на позначення представників інших національностей і детермінують їх сприйняття в інших культурах. Так, наприклад, загально відомим $\epsilon$ уявлення про українців, які їдять виключно борщ, пампушки з часником і салом та вареники з різною начинкою. Проте українці добре знають інші національні кухні, із задоволенням вживають в їжу страви європейської кухні і - відповідно - вмі- 
ють їх готувати. Особливого поціновування набули страви італійської кухні, а їхні назви давно ввійшли в українську мову як запозичення різного ступеня адаптації. Але лексико-семантична група «італійська їжа» в уявленні українців має гетерогенний і неусталений характер, що спричиняє певні непорозуміння під час міжкультурного спілкування, зумовлені стереотипним сприйняттям цього поняття. Зважаючи на це, потребують аналізу особливості сприйняття українцями поняття «національна італійська їжа», на вербальному рівні презентоване насамперед номінаціями страв і напоїв.

Ступінь дослідження проблеми в лінгвістиці. Номінації їжі страв і напоїв перебувають у колі наукових зацікавлень лексикологів, які зосереджують увагу на фаховій мові кулінарії (Г. Мелех), на термінах-кулінаронімах (А. Бохнакова), на концептофері «їжа» (I. Миронова, О. Савельєва та ін.), на глютонічному (гастрономічному) дискурсі (А. Олянич, Е. Бараташвілі, Н. Головницька, I. Державецька, А. Земскова, М. Ундрицова та ін.), на гастрономічній метафориці (О. Афоніна, О. Бойчук, О. Дормідонтова, І. Пахова та ін.), на мовленнєвому жанрі кулінарного рецепта (П. Буркова, О. Руфова та ін.) тощо. Автором терміна глютонічний (гастрономічний) дискурс $є$ А. Олянич, який насамперед звертав увагу на лінгвокультурну та етнокультурну специфіку номінацій їжі [5, c. 168].

Мета наукової розвідки - здійснити експериментальне дослідження мешканцями України поняття італійської національної кухні, зокрема їжі і напоїв. Мета потребувала розв'язання наступних завдань: виявити особливості вербального наповнення тематичної групи «національна їжа та напої»; провести опитування серед мешканців України для виявлення вербальних складників цієї тематичної групи; проаналізувати результати опитування та визначити основні стереотипні уявлення про італійську кухню в українській лінгвоментальності.

Об'скт дослідження - вербальні маркери гетеростереотипів сприйняття італійської національної кухні українцями, а предмет - мовні репрезентанти тематичної групи «італійська їжа» у свідомості українців.

Викладення результатів дослідження. Номінації їжі та напоїв завжди слугували одним із засобів національної ідентифікації людини. Звідси й численні номінації представників різних національностей за кулінарними уподобаннями й пріоритетами: макаронники, жабоїди, бульбаші тощо. На думку Р. Срмакової, людина не може жити без їжі, «однак у представників кожної нації є власні комплекси смакових уподобань, що знаходять втілення у відповідному мовному і текстовому матеріалі: гастрономічній термінології, рецептах національної кухні, меню, кулінарних статтях тощо» [2, с. 3]. Національна кухня поступово стала маркером національної ідентичності разом з іншими культурними надбаннями. Їжа $є$ тим «підгрунтям, на якому вибудовується загальна парадигма світосприйняття і діяльності людини» [7, с. 4]. Але якщо мова, література, музика, архітектура тощо маркують духовне життя народу, то їжа і напої - мате- 
ріальне. Не випадково назви національних страв належать до безеквівалетної лексики - їх переважно відтворюють у перекладі за допомогою транслітерації або транскрибування. В українській мові таких назв на позначення національних страв чимало, напр., з французької мови - круасан, бешамель, крем-брюле, суфле; з іспанської - паелья, пучеро, хамон, гаспачо; з німецької - шніцель, штолен; з японської - суші, сашімі. Не стала винятком італійська мова, з якої запозичено лексеми паста, піца, лазанья тощо, що позначають поширені в Україні та добре знайомі українцям страви.

Традиційно кулінарну лексику потрактовують як тематичну групу (далі TГ) (Ю. Воробйова, 3. Козирєва) або лексико-семантичне поле (далі - ЛСП), у межах якого виокремлюють лексико-семантичні групи (далі - ЛСГ): «інгредієнти», «страви», «посуд та інвентар», «напої», «позначення кулінарних процесів», «властивості» [4, с. 12-13]. 3. Козирєва наголошує на тому, що ТГ «їжа» становить «багаторівневу, певним чином організовану, проте не замкнену систему, в якій елементи об'єднуються в лексико-семантичні групи на основі родо-видових, синонімічних відношень за загальною і диференційною семантичними ознаками і спільності значень, що їх вони виражають» [3, с. 51]. Останнім часом мовознавці визнають засадничу роль кулінарної лексики або глютонічного дискурсу у формуванні національної картини світу, навіть використовують поняття «кулінарна картина світу» (О. Добренко [1]), що зумовлює виокремлення лінгвокультурної категорії «їжа» [6, с. 16]. Ми це явище потрактовуємо як тематичну групу, у межах якої виокремлюємо ЛСГ з відповідним семантичним наповнення. Однією 3 підгруп ТГ «їжа» вважаємо тематичну підгрупу «італійська їжа», що у свідомості українців є досить неоднорідною: пересічні носії мови спрощують поняття італійської культури та обмежують уявлення про національну кухню 2-3 стравами.

Для з'ясування специфіки сприйняття італійської їжі носіями української мови ми провели експериментальне дослідження психолінгвістичного характеру: було опитано 50 інформантів задля виявлення комплексу асоціатів до словосполучення «італійська їжа». В експерименті взяли участь переважно мешканці Одеської області (інформанти 35-70 років) та інших регіонів України (інформанти 16-34 років). До останньої групи здебільшого належали студенти і випускники вишів м. Одеси. Інформанти позначили в анкетах українську як мову спілкування і відповідали українською мовою. Завданням інформантів було упродовж однієї хвилини без підготовки записати 3-5 назв національної італійської кухні. Гіпотеза експерименту полягала в тому, що представники української лінгвоментальності не завжди правильно ідентифікують страви як італійські, а також мають досить однобічне уявлення про італійську їжу, що буде виражатися у наведенні 1-2 відомих назв здебільшого стереотипного характеру (піия, макарони). Методом вільного асоціативного експерименту було встановлено перелік лексем, що, на думку інформантів, належать до лексико-семантичної підгрупи «італійська їжа», що уможливило отримати загалом 
185 вербальних реакцій, серед яких виокремлено 32 асоціата-номінації, більшість повторюваного характеру: паста (36), піща (24), спагеті (14), макарони (6), лазанья (20), ризото (14), равіолі (10), тірамісу (8), моцарела (6), брускета (6), канелоні (4), карбонаро (4), чизкейк (2), паелья (4), песто (6), желато (1), чіабата (4), восьминоги (1), міністроне (1), пана кота (1), паніні (1), лапша (1), мартіні (4), кава «Лаваща» (1), амарето (1), маргарита (1), лімончело (1), граппа (1), к'янті (1), таспачо (1), фетучіні (1), панцанела (1).

Серед наведених вербальних реакцій представлено дві тематичні групи: «їжа» (175) i «напої» (10), що є неоднорідними як за семантикою, так і за походженням. На семантичному рівні тематична група «їжа» представлена ЛСГ «перша страва» (таспачо, міністроне), «основна страва» (паста, піияа, лазанья, равіолі тощо), «закуска» (брускета, паніні), «десерт» (чизкейк, тірамісу, пана кота тощо), «салат» (панщенела), «соус» (песто), «хлібні вироби» (чіабата), «інгредієнти» (моцарела, восьминоги). ТГ «напої» охоплює ЛСГ «алкогольні напої» (мартіні, амарето, маргарита тощо) та безалкогольні напої» (кава).

Найчисленнішою є група номінацій у ЛСГ «основна страва»: nacma, niųa, спагеті, макарони, лазанья, ризото, равіолі, канелоні, карбонаро, паелья, лапша, фетучіні (12 номінацій, що становить 38\% від загальної кількості отриманих асоціатів), у межах якої представлено 138 вербальних реакцій (75\% від загальної кількості поданих реакцій). За походженням у цій групі не всі назви страв $\epsilon$ італійськими: так, номінація «паелья» демонструє уналежнення іспанської страви до італійських, до того ж таких реакцій 4 ( $2 \%$ від загальної кількості реакцій). До помилкової ідентифікації зараховуємо і лексему «лапша» (укр. локшина), що є макаронним виробом, але не італійського, а китайського походження. Серед номінацій основних страв прогнозовано переважають назви, пов'язані з макаронними виробами, тобто це традиційна італійська страва паста та її різновиди (карбонара, фетучіні, канелоні). До лексико-семантичної підгрупи «макаронні вироби» належать родова лексема «паста» (36 реакцій) і видові номінації спагеті, макарони, лапша та назви пасти як страви (30 реакцій) - загалом 60 реакцій (32\%). Отже, третина поданих реакцій вказують на стереотипне сприйняття італійської їі як макаронних виробів. Другою за частотністю $є$ номінація другої страви «піца» (24 реакції - 13\% від загальної кількості поданих реакцій), що також належить до стереотипних уявлень про національну італійську їжу. Меншою частотністю характеризуються номінації таких страв, як лазанья (20 реакцій - 11\%), ризото (14 реакцій - 8\%) і равіолі (10 реакцій $-5 \%)$, проте загалом ці національні страви названі інформантами як італійська їжа. Зважаючи на це, загальна кількість реакцій в цій підгрупі становить 44 , тобто $24 \%$ від загальної кількості поданих на стимул.

Інші ЛСГ значно менш частотні як на рівні номінацій, так і вербальних реакцій. Другою групою номінацій за кількісним показником у ТГ «їжа»є «десерт»: тірамісу, чизкейк, желато, пана кота (4 номінації-13\%, 12 реакцій - 6\%). Серед наведених номінацій частотними є тірамісу (8 реакцій $-4 \%$ ) i 
чизкейк (2 реакції - 1\%), інші мають поодинокий характер. Якщо перша $є$ назвою італійського десерту, то друга походить 3 англійської мови і співвідноситься $з$ десертом із солодкого сиру, поширеним в інших країнах Європи та США. Спостерігаємо помилкову ідентифікацію страви, хоч і не настільки масову, як у випадку з назвою іспанської основної страви «ризото».

У ЛСГ «перша страва» (2 номінації - 0,6\%) представлено лексеми тасnачо, міністроне, що мають поодинокий характер, при цьому у першому випадку йдеться про страву іспанської, а не італійської кухні. Як бачимо, змішування іспанських та італійських страв характерне явище для лінгвосвідомості інформантів, що пояснюємо приналежністю обох мов до романської групи і фонетичною близькістю лексичних одиниць. У ЛСГ «закуска» брускета, паніні теж представлено дві номінації з поодинокими реакціями, в обох випадках йдеться про італійські назви бутербродів, в ЛСГ «інгредієнт» також дві номінації (моцарела, восьминоги) поодинокого характеру. Ці ЛСГ демонструють обізнаність інформантів з екзотичними стравами та компонентами страв італійської кухні, а певною мірою і прагненням продемонструвати свою обізнаність. Поодинокий характер мають асоціації, що належать до ЛСГ «салат» (панценела), ЛСГ «соус» (песто) і ЛСГ «хлібні вироби» (чіабата), що належать до італійської їжі.

ТГ «напої» значно менш частотна, але потрібно мати на увазі, що завданням інформантів було подати асоціації до стимулу «італійська їжа», а не напої. Незважаючи на це, деякі учасники експерименту назвали назви напоїв, при цьому деякі мають непоодинокі реакції, зокрема мартіні (4 реакції - 2\%). Цей напій у більшості інформантів асоціюється з Італією, за походженням його пов'язують 3 прізвищем винахідника Алессандро Мартіні з Турина. Інші асоціації: кава «Лавача» (1), амарето (1), маргарита (1), лімончело (1), грапа (1), к’янті (1). Серед наведених номінацій лише одна вказує на безалкогольний напій, проте неіталійський за походженням, утім, зазначено італійську торгову марку кави, дуже популярну в Україні. Номінації алкогольних напоїв також не всі належать до італійських: так, коктейль «Маргарита» має латиноамериканське коріння. Інші номінації є назвами здебільшого алкогольних напоїв 3 винограду італійські за походженням.

Висновки дослідження. Якщо узагальнювати образ тематичної підгрупи «італійська їжа» у лінгвосвідомості носіїв української мови, то потрібно зазначити його стереотипність і суперечливість. 3 одного боку, інформанти продемонстрували обізнаність 3 найвідомішими лексемами на позначення італійських страв (макаронних виробів і піци), а з іншого боку, намагалися виявити обізнаність 3 екзотичними, маловідомим назвами, іноді зараховуючи до італійських іспанські та англійські за походженням номінації. Носії української мови подавали частотні вербальні реакції з номінаціями других страв італійської кухні, натомість інші ЛСГ представлені обмежено. Це стосується і ТГ «напої», яка виявилася в межах представлених асоціатів. Отже, гіпотезу підтверджено 
частково: відзначаючи проблеми з ідентифікацією номінацій страв італійської кухні (навність реакцій, помилкових за походженням) та певну стереотипність їхньої презентації (нерівнозначне співвідношення малої кількості асоціацій 3 великою кількістю реакцій), наголосимо на прагненні інформантів продемонструвати обізнаність 3 італійською кухнею через використання маловідомої лексики на позначення страв.

\section{Література}

1. Добренко Е. Гастрономический коммунизм: вкусное vs здоровое. Неприкосновенный запас: дебаты о политике и культуре. 2009. № 2. С. 155-173.

2. Ермакова Л. Р. Глюттонические прагматонимы и национальный характер: на материале русской и английской лингвокультур: автореферат дисс. канд. філол. наук. Белгород, 2011. 20 с.

3. Козирєва 3. Г. Українська когнітосфера «їжа» як предмет лінгвістичного дослідження. Науковий вісник кафедри Юнеско КНЛУ. Серія Філологія, педагогіка, психологія. 2014. Вип. 29. C. $48-55$.

4. Мелех Г. Б. Німецька фахова мова кулінарії: системно-структурні та функційно-семантичні аспекти: автореферат дис. канд. філол. наук. Чернівці, 2018. 20 с.

5. Олянич А. В. Презентационная теория дискурса. Волгоград: Парадигма, 2004. С. 397-420.

6. Савельева О. Г. Концепт «еда» как фрагмент языковой картины мира: лексико-семантический и когнитивно-прагматический аспекты: на материале русского и английского языков: автореферат дисс. канд. філол. наук. Краснодар, 2006. 20 с.

7. Шхумишкова А. Р. Номинации понятийной сферы «пища»: автореферат дисс. канд. філол. наук. Майкоп, 2011. 20 с.

\section{References}

1. Dobrenko E. Hastronomycheskyy kommunyzm: vkusnoe vs zdorovoe [Gastronomic communism: tasty vs healthy]. Neprykosnovennyy zapas: debaty o polytyke y kul'ture. 2009. № 2. S. 155-173.

2. Ermakova L. R. Hlyuttonycheskye prahmatonymy y natsyonal'nyy kharakter: na materyale russkoy y anhlyyskoy lynhvokul'tur [Gluttonic pragmatonyms and national character: on the material of Russian and English linguocultures:]: avtoreferat dyss. kand. filol. nauk. Belhorod, 2011. $20 \mathrm{~s}$.

3. Kozyryeva Z. H. Ukrayins'ka kohnitosfera «yizha» yak predmet linhvistychnoho doslidzhennya [Ukrainian cognosphere "Yizha" as the subject of linguistic dosage]. Naukovyy visnyk kafedry Yunesko KNLU. Seriya Filolohiya, pedahohika, psykholohiya. 2014. Vyp. 29. S. 48-55.

4. Melekh H. B. Nimets'ka fakhova mova kulinariyi: systemno-strukturni ta funktsiyno-semantychni aspekty [German professional language of cooking: system-structural and functional-semantic aspects]: avtoreferat dys. kand. filol. nauk. Chernivtsi, 2018. $20 \mathrm{~s}$.

5. Olyanych A. V. Prezentatsyonnaya teoryya dyskursa [Presentation theory of discourse]. Volhohrad: Paradyhma, 2004. S. 397-420.

6. Savel'eva O. H. Kontsept «eda» kak frahment yazykovoy kartyny myra: leksyko-semantycheskyy y kohnytyvno-prahmatycheskyy aspekty: na materyale russkoho y anhlyyskoho yazykov [Concept "food" as a fragment of the linguistic picture of the world: lexical-semantic and cognitive-pragmatic aspects: on the material of Russian and English languages]: avtoreferat dyss. kand. filol. nauk. Krasnodar, 2006. 20 s.

7. Shkhumyshkova A. R. Nomynatsyy ponyatyynoy sferi «pyshcha» [Nominations of the conceptual sphere of "food"]: avtoreferat dyss. kand. filol. nauk. Maykop, 2011. 20 s. 


\section{Kondratenko N. V.}

\section{STEREOTYPICAL PERCEPTION OF TOKENS OF THE THEMATIC GROUP «ITALIAN FOOD» BY NATIVE SPEAKERS OF THE UKRAINIAN LANGUAGE}

The article considers the nominations of dishes and drinks of Italian cuisine, which are popular in Ukraine and have appropriate names in the Ukrainian language. The study presents the results of a linguistic experiment, which was stimulated by the phrase - the nomination of the lexical-semantic group "Italian food". The complex of received tokens is singled out, the character of semantic connections and the main semantic groups of nominations are determined, and also the peculiarities of informants' perception of the concept of "Italian food" are traced, which included both food and drink nominations. Thematic groups of vocabulary for the designation of Italian dishes and drinks obtained as a result of the conducted linguistic experiment are determined. The stereotypical nature of the perception of Italian food and drinks by native speakers of the Ukrainian language is substantiated.

Key words: linguistic consciousness, linguistic experiment, lexical-semantic group, nomination of dishes, verbal reaction. 